\title{
Screening the Efficacy of different Fungicides against Fusarium oxysporum f. sp. ricini in Castor
}

\author{
Shalini Yerukala $^{1 *}$, Vidya Sagar Bokka ${ }^{1}$ and Giribabu Palaniappan ${ }^{2}$ \\ ${ }^{1}$ Department of Plant Pathology, Professor Jayashankar Telangana State Agricultural \\ University, College of Agriculture, Rajendranagar, Hyderabad, Telangana500030, India \\ ${ }^{2}$ Indian Institute of Oilseeds Research, Rajendranagar, Hyderabad, Telangana500030, India \\ *Corresponding author
}

\section{A B S T R A C T}

Keywords

Castor, F. oxysporum f.sp. ricini, in-vitro bioassay, fungicides, inhibition

Article Info

\section{Accepted:}

12 April 2021

Available Online: 10 May 2021
Castor (Ricinus communis L.) is one of the major oilseed crops grown all over India. The castor crop is majorly affected by the castor wilt disease caused by Fusarium oxysporum f.sp. ricini, which cause severe crop yield loses. Understanding the importance of the castor wilt disease, we conducted an in-vitro bioassay to test the commercially available fungicides inhibition effect on the castor wilt fungus F.oxysporum f.sp. ricini. The fungicides tested include carbendazim, carboxin, thiram, metalaxyl and blitox at recommended and half-recommended dosage against castor wilt fungus. Among the five fungicides tested by poisoned food technique, carbendazim was found superior at both recommended and halfrecommended doses with 100 percent inhibition of the test pathogen.

\section{Introduction}

Castor (Ricinus communis L.) is an ancient crop of family Euphorbiaceae, cultivated across the world in arid and semi-arid zones (Weiss, 2000; Castor Outlook, October 2019)in almost thirty different countries. The global castor production is noted to be 15.4 lakh million tones(FAO, 2008; Yerukala et al., 2017; Shalini, 2014). The major castor seed growing countries includes India, Brazil, Philippines, China, Russia, Ethiopia, and
Thailand accounting almost 88 percent of the world's production (Castor Outlook, October 2019).

Castor plays an important role in Indian vegetable oil economy. The India ranks first in area with 10.96 lakh ha and production with 11.43 lakh toneof castor in the world, which includes major castor producing states Gujarat, Rajasthan, and Andhra Pradesh etc. Andhra Pradesh accounts for about area 2.22 lakh ha with yield of $675 \mathrm{kgha}^{-1}$ (Indiastat, 
2013; Shalini et al., 2014). Moreover, in the year 2019, in India the castor oil seed area harvested was 751320 ha; yield 15928 hg(hectogram)/ha; while crop production was 1196680 tones(FAO, 2019). The major castor producing states in India include Gujarat (7.02 lakh ha) followed by Rajasthan (1.54 lakh ha), Andhra Pradesh (0.33 lakh ha), Telangana (0.22 lakh ha) and Odisha (0.04 lakh ha) (Castor Outlook, October 2019). While in Telangana state, the major castor growing districts include Narayanpet (6973 ha) followed by Wanaparthy $(5567$ ha), Mahabubnagar (5104 ha) and Gadwal (2163 ha) (Castor Outlook, October 2019).

The castor crop is affected majorly by castor fusarium wilt disease caused by the pathogen Fusarium oxysporum f.sp. ricini, which belongs to the kingdom fungi: phylum ascomycota; subphylum pezizomycotina (EPPO, 2021). Further, castor fusarium wilt is found to cause huge crop losses almost up to eighty five percent depending on pathogen inoculum and prevailing environmental conditions (Dange, 2003).

Additionally, castor fusarium wilt being a soil and seed borne pathogen (Prasad et al., 2019; Dange, 2003), colonizes the plant xylem vessels and block them completely causing plant wilting (Dange, 2003). Generally, for the control of this disease fungicides are used (Maitlo et al., 2014). Further many varieties of chemicals are available in the market for the control of this disease. Despite, there exists a research gap with respect to the necessity to evaluate the efficacy of the chemicals, and dosage applied against the target pathogen before usage. The present study investigated on finding the effectiveness and optimum fungicide recommended dose and half recommended dosage of popularly available fungicides used in fusarium wilt disease control by an in-vitro bioassay.
Therefore, the present study was carried out to fill the gaps. And compare the efficiency of various fungicides available commercially in market against Fusarium oxysporum f. sp. ricini, the fusarium wilt of castor disease by an in-vitro bioassay. The best fungicide performed against fusarium wilt pathogen in the in-vitro bioassay, is further used for green house and open environment pot experiment studies in testing the castor fusarium wilt management.

\section{Materials and Methods}

All the experiments were performed at the Department of Plant Pathology, College of Agriculture, Hyderabad, India. The efficacy of different commercially available fungicides (Table 1) was tested by poisoned food technique (Nene and Thapliyal, 1993; Yerukala et al., 2018) against $F$. oxysporum $\mathrm{f}$. sp. ricini by measuring the radial growth of the fungal colony. For each treatment, potato dextrose agar (PDA) medium $(100 \mathrm{ml})$ was taken in conical flask $(250 \mathrm{ml})$ and autoclaved. To this medium, specified concentration of fungicide was added to the medium at lukewarm temperature and mixed thoroughly by shaking the flask. The poisoned medium was equally distributed into four petri dishes, which were treated as four replications and the medium was kept for solidification. Simultaneously, from periphery of actively growing fungal colony of target pathogen $(F$. oxysporum f.sp. ricini), a $5 \mathrm{~mm}$ fungal discs was cut with sterilized corn borer. A fungal disc was transferred to the center of each petri dish containing poisoned medium. For control treatment, the petri dish containing untreated (not poisoned) medium was maintained by placing fungal disc. The inoculated petri dish was incubated at $25 \pm 22^{\circ} \mathrm{C}$ in BOD (BioOxygen Demand). The diameter of the fungal colony was measured in two directions and mean was recorded when the fungal growth in control petri dish was full. 
Percent inhibition over control was calculated using the formula mentioned below.

$\mathrm{R}=(\mathrm{X}-\mathrm{Y}) / \mathrm{X} \times 100$

Where, $\mathrm{R}=$ Per cent growth reduction of test pathogen,

$\mathrm{X}=$ Radial growth of test pathogen in control $(\mathrm{mm})$

$\mathrm{Y}=$ Radial growth of test pathogen in treatment $(\mathrm{mm})$

The research data results obtained was transformed by angular transformations and statistically analyzed by CRD Completely Randomized Design (Snedecor and Cochran, 1967). Both actual percentage values and their corresponding transformed values are presented in Table 2.

\section{Results and Discussion}

The present research results on evaluating different fungicides against $F$. oxysporum $\mathrm{f}$. sp. ricini in-vitro condition are presented in Table 2 and Figures 1 and 2. In our research, we found that all the fungicides tested were significantly superior over control in inhibiting the fungal growth of $F$. oxysporum f.sp. ricini. However, high inhibition (100 percent) of radial growth of test pathogen $F$. oxysporum f.sp. ricini was recorded by the fungicide carbendazim at both the recommended and half the recommended doses, while minimum inhibition was recorded by metalaxyl at the recommended $(82.86$ percent) and half the recommended doses (77.86 percent). At recommended dose carbendazim and vitavax recorded maximum (100 percent) fungal growth inhibition of test pathogen significantly followed by blitox (93.70 percent), thiram (91.94 percent) and metalaxyl (82.86 percent) and all the treatments were found statistically significant.
At half recommended dose carbendazim recorded maximum (100 percent) fungal growth inhibition of test pathogen significantly followed by vitavax $(98.88$ percent), thiram (89.80 percent), blitox (88.33 percent) and metalaxyl (77.86 percent). All the treatments were found statistically significant.

Similar research results showing fungicide carbendazim, high effectiveness on fungal growth inhibition on fusarium pathogen was reported by various research includes Raju et al., 2008 reported against $F$. oxysporum f. sp. udum; while against $F$. solani and $R$. solani by Mallesh et al., 2008; F.oxysporum f. sp. pini (Dar et al., 2013); F. oxysporum f. sp. lentis (Dahal and Shrestha, 2018); $F$. pallidospermum (Jamil and Kumar, 2010); F. oxysporum f. sp. capsica (Bashir et al., 2018); F. avenaceum (Kopacki and Wagner, 2006); F. oxysporum f. sp. lycopersici (Deo, 2013; Harshita et al., 2019); F. solani (Bhaliya and Jadeja, 2014). Some of the studies are detailed below which agree with our research results includes Dahal and Shrestha, 2018 tested different fungicides efficiency against F.oxysporum f. sp. lentis by an in-vitro bioassay using poisoned food technique. The authors used fungicides include carbendazim (50\% WP), chlorothalonil (75\% WP) and dithane M-45 (75\% WP) at three different concentrations (100 ppm, 150 ppm and 200 ppm).

All the tested fungicides showed significant inhibition of fungal growth of the test pathogen, however carbendazim recorded high effectiveness in inhibition of fungal growth in all the concentrations tested by reducing the mycelial growth by 100 percent compared to others; followed by chlorothalonil, and least recorded inhibition was with Dithane M-45 (26.62 percent) at $200 \mathrm{ppm}$. Further authors noted that, with the increased fungicides concentration, increased inhibition of target pathogen. 
Table.1 List of fungicides used against Fusarium oxysporum f. sp. ricini

\begin{tabular}{|c|c|c|c|c|}
\hline S.No & Common Name & Trade Name & Formulation & Chemical name \\
\hline 1. & Carbendazim & Bavistin & $50 \mathrm{WP}$ & $\begin{array}{c}\text { 2-(methoxy carbomyl )- } \\
\text { benzimidazole }\end{array}$ \\
\hline 2. & Carboxin & Vitavax & $75 \mathrm{WP}$ & $\begin{array}{l}\text { 5,6-dihydro-2-methyl-1,4- } \\
\text { oxathiin-3-carboxamide }\end{array}$ \\
\hline 3. & Thiram & $\begin{array}{l}\text { Thirasan } \\
\text { Thirame, } \\
\text { Thiuramin }\end{array}$ & $75 \mathrm{WP}$ & tetramethylthiuram disulfide \\
\hline 4. & Metalaxyl & Apron, Ridomil & $50 \mathrm{WP}$ & $\begin{array}{l}\mathrm{N}-(2,6-\text { dimethylphenyl)-N- } \\
\text { (methyoxyacetyl)-alanine } \\
\text { methyl ester }\end{array}$ \\
\hline 5. & Blitox & Blitox & $50 \mathrm{WP}$ & Copper oxychloride \\
\hline
\end{tabular}

Table.2 In vitro evaluation of fungicides against Fusarium oxysporum $\mathrm{f}$. sp.ricini

\begin{tabular}{|c|c|c|c|c|}
\hline \multirow[t]{3}{*}{ S.No } & \multirow[t]{3}{*}{ Fungicides } & \multicolumn{3}{|c|}{ *Per cent growth inhibition } \\
\hline & & \multicolumn{3}{|c|}{ Concentration } \\
\hline & & Recommended & $\begin{array}{c}\text { Half } \\
\text { recommended }\end{array}$ & Mean \\
\hline 1. & Carbendazim & $\begin{array}{l}100.00 \\
(85.94)\end{array}$ & $\begin{array}{l}100.00 \\
(85.94)\end{array}$ & 100.00 \\
\hline 2. & Vitavax & $\begin{array}{l}100.00 \\
(85.94)\end{array}$ & $\begin{array}{c}98.88 \\
(83.93)\end{array}$ & 99.44 \\
\hline 3. & Thiram & $\begin{array}{c}91.94 \\
(73.51)\end{array}$ & $\begin{array}{c}89.80 \\
(71.48)\end{array}$ & 90.87 \\
\hline 4. & Metalaxyl & $\begin{array}{c}82.86 \\
(65.55)\end{array}$ & $\begin{array}{c}77.86 \\
(61.94)\end{array}$ & 80.36 \\
\hline 5. & Blitox & $\begin{array}{c}93.70 \\
(75.63)\end{array}$ & $\begin{array}{c}88.33 \\
(70.02)\end{array}$ & 91.01 \\
\hline 6. & Control & $\begin{array}{c}0.00 \\
(4.05)\end{array}$ & $\begin{array}{c}0.00 \\
(4.05)\end{array}$ & 0.00 \\
\hline & Mean & 78.08 & 75.81 & 76.94 \\
\hline CD at $5 \%$ & & 2.13 & 2.04 & 2.08 \\
\hline S.Ed \pm & & 0.97 & 0.93 & 0.95 \\
\hline S.Em \pm & & 0.69 & 0.66 & 0.67 \\
\hline
\end{tabular}

*Mean of four replications, figures in the parentheses are angular transformed values 
Fig.1 Efficacy of fungicides on Fusarium oxysporum f.sp. ricini

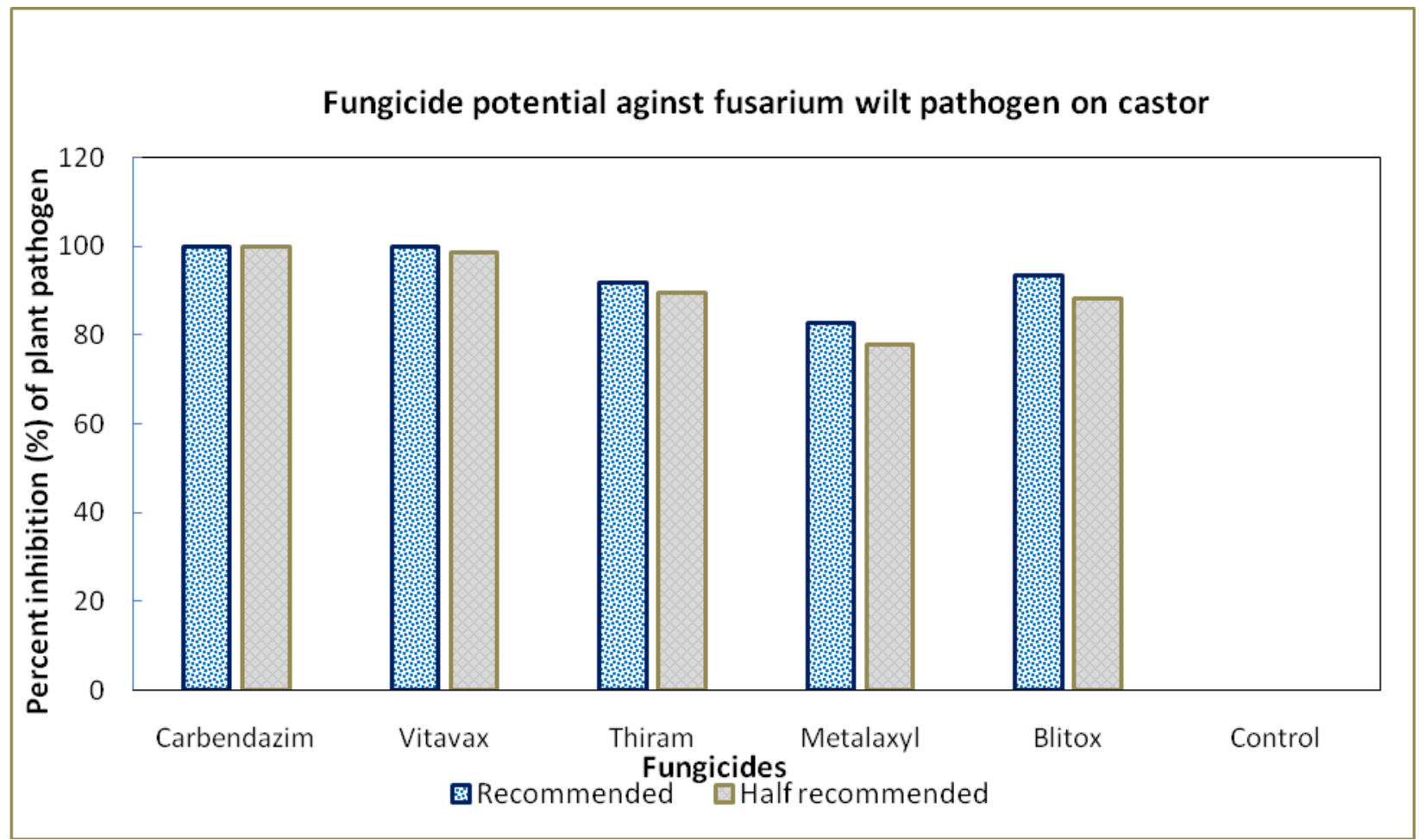

Fig.2 Efficacy of fungicides on Fusarium oxysporum f.sp. ricini

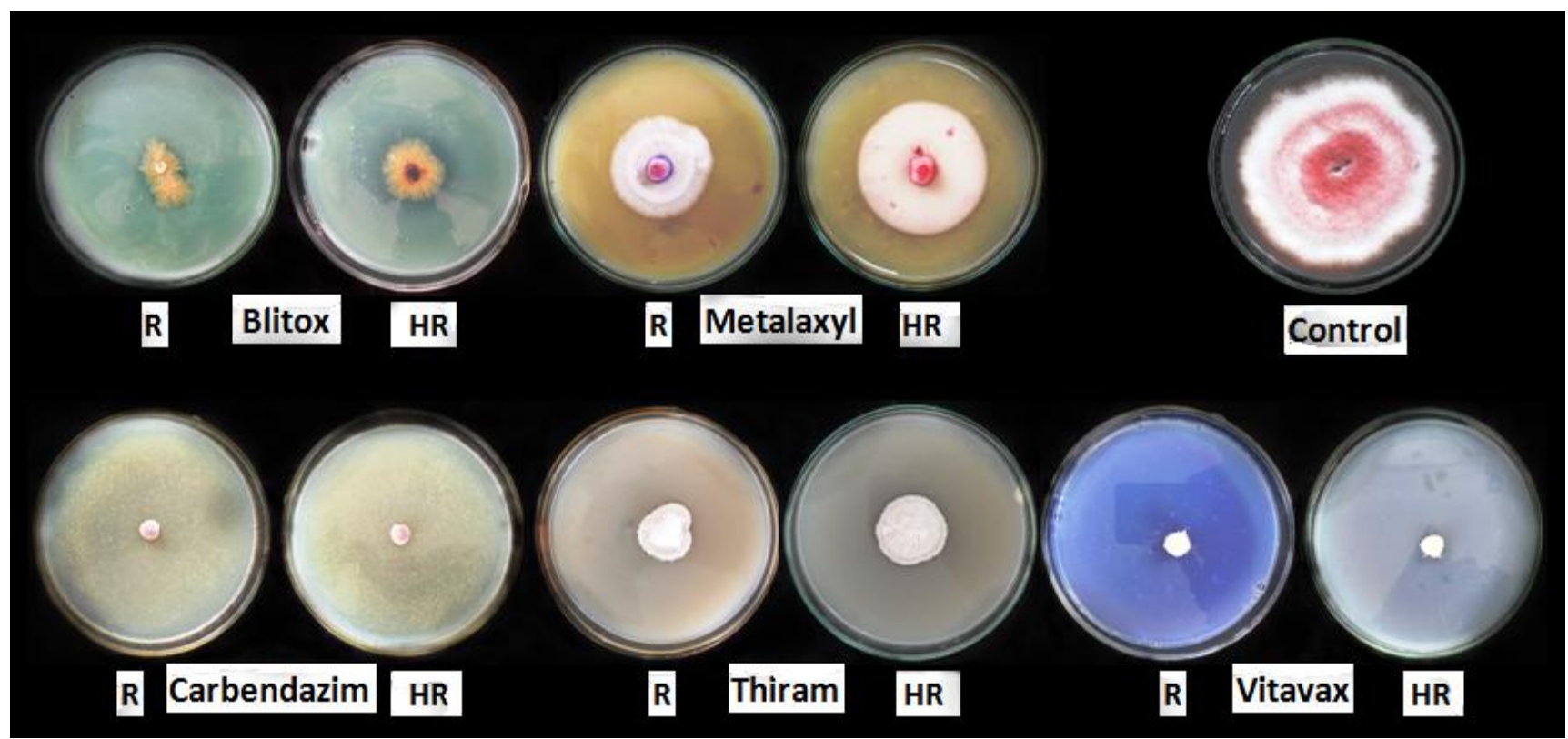

$* \mathrm{R}=$ Full recommendation, HR-Half recommended 
Dar et al., 2013 reported $F$. oxysporum f. sp. pini sensitivity to the fungicides carbendazim, thiaphonate methyl, hexaconazole, triadimefon, mancozeb, metalaxyl, captan, copper oxychloride and chlorothalonil.

The authors tested different fungicides efficiency against F.oxysporum f. sp. piniby in-vitro bioassay using poisoned food technique. The authors used systemic fungicides include hexaconazole, triadimefan, carbendazim, thiophonate methyl, metalaxyl evaluated at 5 different concentrations $(10,20$, 30, 40, $50 \mathrm{ppm})$; non-systemic fungicides include copper oxychloride, mancozeb, chlorothalonil and captan evaluated at 5 different concentrations (100, 200, 300, 400 and $500 \mathrm{ppm}$.

Among fungicides tested, carbendazim was most effective with maximum inhibition of target pathogen (F.oxysporum f. sp. pini) compared to the other chemicals tested. In similar Jamil and Kumar (2010) evaluated fungicides carbendazim, mancozeb, maneb, thiram and ziram against F.pallidospermum, the research found that carbendazim was most effective, additionally carbendazim showed broad spectrum fungitoxic activity against four species of Fusarium ( $F$. equseti; $F$. moniliformae; $F$. pallidospermum; $F$. solani). Dilip (1989), who reported that carbendazim at $1000 \mathrm{ppm}$ showed maximum fungal growth inhibition of pathogen $F$. oxysporum f. sp. nicotianae (tobacco wilt).

Bashir et al., 2018, tested efficacy of different fungicides in-vitro against $F$. oxysporum $\mathrm{f}$. sp. capsica (chilli pepper wilt) by poisoned food technique. Among 6 treatments tested include carbendazim, benomyl, topsin-m, difenoconazole, nativo, alliete and control at various concentrations, and days, and their interactions. Among all treatments tested, carbendazim at $700 \mathrm{ppm}$ recorded significant reduction of pathogen growth. Similarly,
Khadse et al., 2015. tested efficacy of different fungicides against Neocosmospora vasinfecta (pigeon pea wilt) in-vitro by poisoned food technique. The different fungicides tested include thiram, carbendazim, chlorothalonil, metalaxyl, combinations treatments include thiram + cabendazim(2:1), carbendazim + mancozeb, tricyclazole+ mancozeb, zineb+hexaconazole was evaluated against the target pathogen.

Among all treatments tested, carbendazim $(0.1 \%)$, combination treatments carbendazim+ mancozeb $(0.2 \%)$ and thiram+carbendazim $2: 1 \quad(0.3 \%)$ recorded high (100 per cent) inhibition of $N$. vasinfecta, other fungicides also recorded significant pathogen inhibition over control.

In the present studies we found that carbendazim showed high effectiveness against $F$. oxysporum f. sp. ricini with high percent inhibition (100 percent) at both recommended and half-recommended doses in comparison with other fungicides tested.

Susceptibility of the $F$. oxysporum f. sp. ricini to all the fungicides tested was recorded. Our study provide knowledge on better fungicide dosage evaluation for specific purposes. Further research needed to better understand the susceptibility index and application in field experiments.

\section{Acknowledgements}

The authors are grateful to the College of Agriculture, Rajendhranagar, Hyderabad, India for providing the financial assistance and support for conducting this research.

\section{References}

Bashir, M. R., Atiq, M., Sajid, M., Mohsan, M., Abbas, W., Alam, M. W., and Bashair, M. 2018. Antifungal 
exploitation of fungicides against Fusarium oxysporum f. sp. capsicicausing Fusarium wilt of chilli pepper in Pakistan. Environmental Science and Pollution Research, 25(7), 6797-6801.

Bhaliya, C. M., and Jadeja, K. B. 2014. Efficacy of different fungicides against Fusarium solani causing coriander root rot. The bioscan, 9(3), 1225-1227.

Castor Outlook, October 2019; Agricultural Market Intelligence Centre, PJTSAU https://www.pjtsau.edu.in/files/AgriMk t/2019/oct/Castor-October-2019.pdf

Dahal, N., and Shrestha, R. K. 2018. Evaluation of Efficacy of fungicides against Fusarium oxysporum f. sp. lentis in vitro at Lamjung, Nepal. Journal of the Institute of Agriculture and Animal Science, 35(1), 105-112.

Dange, S. R. S. 2003. Wilt of Castor - An overview. Indian Journal of Mycology and Plant Pathology, 33 (3), 333-339.

Dar, W. A., Beig, M. A., Ganie, S. A., Bhat, J. A., Rehman, S., and Razvi, S. M. 2013. In vitro study of fungicides and biocontrolagents against Fusarium oxysporum f. sp.pini causing root rot of western himalayan fir (Abies pindrow). Scientific Research and Essays, 8(30), 1407-1412.

Deo, N. 2013. The effect of fungicide "carbendazim" on in vitro mycelial growth of two phytopathogenic fungi: Case study of Fusarium oxysporum $\mathrm{f}$. sp. lycopersici" strain F20" and Colletotrichum capsici" strain C226. 3". East African Journal of Science and Technology, 2(2), 76-96.

Dilip, M. 1989. Variability among four isolates of Fusarium oxysporum f. sp. nicotianae causing wilt of Nicotiana rustica. Nicotine and Tobacco Research, 15, 88-91.

EPPO, 2021, European and Mediterranean Plant Protection Organization, EPPO
Global

Database

.https://gd.eppo.int/taxon/FUSARI

FAO, 2008. Food and Agriculture Organization (FAO).

FAO, 2019. Food and Agriculture Organization (FAO) http://www.fao.org/faostat/en/\#data/Q C

Harshita, A. S., Khan, J. B., Tripathi, U. K., Ratan, V., Trivedi, S., Mishra, A., and Verma, A. 2019. In-vitro evaluation of systemic fungicides against Fusarium oxysporum f. sp. lycopersici and their compatibility with bioagents. Journal of Pharmacognosy and Phytochemistry, 8(3), 3117-3123.

INDIASTAT, 2013. Crop statistics in India. www.indiastat.com/

Jamil, S., and Kumar, M. 2010. Evaluation of fungicides against phyllosphere mycoflora of foliage plants. Biological Forum, 2(1), 56-59.

Khadse, R. R., Giri, G. K., Raut, S. A., and Bhoye, B. B. 2015. In vitro efficacy of fungicides and bioagents against wilt of pigeonpea caused by Neocosmospora vasinfecta. Science International, 3(3), 82-84.

Kopacki, M., and Wagner, A. 2006. Effect of some fungicides on mycelium growth of Fusarium avenaceum (Fr.) Sacc. pathogenic to chrysanthemum (Dendranthema grandiflora Tzvelev). Agronomy Research, 4, 237-240.

Maitlo, S. A., Syed, R. N., Rustamani, M. A., Khuhro, R. D., and Lodhi, A. M. 2014. Comparative efficacy of different fungicides against fusarium wilt of chickpea (Cicer arietinum L.). Pakistan Journal of Botany, 46(6), 2305-2312.

Mallesh, S. B., Narendrappa, T., and Satish, D. 2008. Evaluation of different fungicides and plant extracts against Fusarium solani and Rhizoctonia solani, the causal agents of root rot of 
Sage (Salvia officinalis Linn). International Journal of Plant Sciences, 3 (1), 82-86.

Nene Y. L., and Thapliyal, P. N. 1993. Fungicides in Plant Disease Control, Oxford and IBH Publishing House, New Delhi, 163.

Prasad, M. S. L., Raoof, M. A., Gayatri, B., Anjani, K., Lavanya, C., Prasad, R. D., and Senthilvel, S. 2019. Wilt disease of castor: an overview. Indian Phytopathology, 72(4), 575-585.

Raju, G. P. R., S. V.R., and Gopal, K. 2008. In vitro evaluation of antagonists and fungicides against the red gram wilt pathogen Fusarium oxysporum f. sp. udum (Butler) Snyder and Hansen. Legume Research, 31(2), 133-135.

Shalini, Y. 2014. Studies on castor (Ricinus communis 1.) wilt complex and its management (Doctoral dissertation, Acharya NG Ranga Agricultural University).https://krishikosh.egranth. ac.in/handle/1/67745

Shalini, Y., Sagar, B. V., Giribabu, P., and Rao, V. K. 2014. Management of wilt disease complex in castor. Indian Journal of Plant Protection, 42(3), 255-258. https://www.semanticscholar.org/pape r/Management-of-wilt-diseasecomplex-in-castor-ShaliniSagar/e4d265b8fdeaf576c9750765elb b0abf984eb9d8

Snedecor, G. W., and Cochran, W. G. 1967. Statistical methods. Oxford and IBH Publishing Company, New Delhi, 593, 151-156. https://goo.gl/Zxk5BM

Weiss, E. A.2000. Oilseed crops. 2nd ed Blackwell Science, Oxford.

Yerukala, S., Bokka, V. S., and Palaniappan, G. 2018. Botanical based protection could be a sustainable alternative in management of castor (Ricinus communis) wilt caused by Fusarium oxysporum f. sp. ricini. International Journal of Current Microbiology and Applied Sciences, 7(7), 3011-3022. https://doi.org/10.20546/ijcmas.2018.7 07.352

Yerukala, S., Bokka, V. S., Palaniappan, G., and Rao, V. K. 2017. Efficacy of fungal versus bacterial bioagents on fusarium wilt of castor. International Journal of Current Microbiology and Applied Sciences, 6(11), 1230-1239. https://doi.org/10.20546/ijcmas.2017.6 11.146

\section{How to cite this article:}

Shalini Yerukala, Vidya Sagar Bokka and Giribabu Palaniappan. 2021. Screening the Efficacy of different Fungicides against Fusarium oxysporum f. sp. ricini in Castor. Int.J.Curr.Microbiol.App.Sci. 10(05): 316-323. doi: https://doi.org/10.20546/ijcmas.2021.1005.039 